IZA DP No. 4632

Does Public Information about School Quality

Lead to Flight from Low-Achieving Schools?

Jane Friesen

Mohsen Javdani

Simon Woodcock

December 2009 


\title{
Does Public Information about School Quality Lead to Flight from Low-Achieving Schools?
}

\author{
Jane Friesen \\ Simon Fraser University \\ Mohsen Javdani \\ Simon Fraser University \\ Simon Woodcock \\ Simon Fraser University \\ and IZA
}

Discussion Paper No. 4632

December 2009

\author{
IZA \\ P.O. Box 7240 \\ 53072 Bonn \\ Germany \\ Phone: +49-228-3894-0 \\ Fax: +49-228-3894-180 \\ E-mail: iza@iza.org
}

\begin{abstract}
Any opinions expressed here are those of the author(s) and not those of IZA. Research published in this series may include views on policy, but the institute itself takes no institutional policy positions.

The Institute for the Study of Labor (IZA) in Bonn is a local and virtual international research center and a place of communication between science, politics and business. IZA is an independent nonprofit organization supported by Deutsche Post Foundation. The center is associated with the University of Bonn and offers a stimulating research environment through its international network, workshops and conferences, data service, project support, research visits and doctoral program. IZA engages in (i) original and internationally competitive research in all fields of labor economics, (ii) development of policy concepts, and (iii) dissemination of research results and concepts to the interested public.
\end{abstract}

IZA Discussion Papers often represent preliminary work and are circulated to encourage discussion. Citation of such a paper should account for its provisional character. A revised version may be available directly from the author. 
IZA Discussion Paper No. 4632

December 2009

\section{ABSTRACT \\ Does Public Information about School Quality Lead to Flight from Low-Achieving Schools?*}

We estimate the effect of publicly disseminated information about school-level achievement on students' mobility between elementary schools. We find that students are more likely to leave their school when poor school-level performance is revealed. In general, parents respond to information soon after it becomes available. Once the information is absorbed, they do not respond to subsequent releases, even when it is reframed and given widespread media attention. Parents in low-income neighborhoods and those who speak a non-English language at home respond most strongly. However, non-English speaking parents only respond when information is widely disseminated and discussed in the media.

JEL Classification: $\quad 121$

Keywords: information, school choice

Corresponding author:

Jane Friesen

Department of Economics

Simon Fraser University

8888 University Drive

Burnaby B.C. V5A 156

Canada

E-mail: friesen@sfu.ca

\footnotetext{
* Alfred Kong and Klaus Edenhoffer provided valuable research assistance and Andreas Ludwig assisted in the collection of school postal codes. The administrative data used in this research were extracted from the B.C. Ministry of Education's student records by Maria Trache at Edudata Canada. We are grateful to Peter Cowley for providing us with the Fraser Institute's school scores and rankings in electronic form. Funding for this project was provided by Simon Fraser University's Community Trust Endowment Fund. We thank Steve Easton, Andrew Chesher and Justin Smith for helpful comments and discussion.
} 
Economists have long argued that policies that increase competition in markets for education can improve educational outcomes by increasing disadvantaged students’ access to high quality schools, and by causing underperforming schools to become more effective or to shrink as families "vote with their feet" (Friedman 1955; Becker 1995; Hoxby 2003). Recent evidence shows that directly providing parents with information about school-level achievement can influence school choice (Hastings and Weinstein 2008). However, whether publicly disseminating school achievement measures through the media has the same effect remains unknown. ${ }^{4}$ On the one hand, widespread dissemination has the potential to influence the choices of many parents, and may therefore substantially increase the effectiveness of school choice policies. However, a large increase in the demand for high-achieving schools will not increase competitive pressure on weaker schools unless preferred schools can actually accommodate more students. Furthermore, children whose parents have poor access to media, or who are not part of wellinformed social networks, may not benefit from public information strategies. Parents could also be misled or confused when education authorities update public information if these measures are subject to substantial sampling variation.

Our study addresses these issues by examining the effect of public information about school achievement on school choice behavior in British Columbia (B.C.). Our estimates are based on student-level longitudinal data on multiple cohorts of students that span the introduction of standardized testing and the subsequent wide dissemination of school-level results. We use a difference-in-difference framework to measure the effect of new information on the probability that public school students move to a different school following Grade 4. We also investigate whether the response to information about school performance differs among parents who may face higher costs of accessing the information.

\footnotetext{
${ }^{4}$ This strategy has been adopted in England (West and Pennell 2000), Chile (Urquiola, McEwan and Vegas 2007), New Zealand (Fiske and Ladd 2000), and many U.S. states (Figlio and Lucas 2004) and Canadian provinces (Cowley 2007).
} 
School-level achievement measures may be correlated with unmeasured characteristics of schools that influence parents' beliefs about school quality and affect student mobility. We identify parents' response to new information using a control function approach that exploits the timing of testing and the release of test results. Parents do not receive information about the exam results of their own child's cohort in the year they take the exams. In the year that students are tested, therefore, the current cohort's exam results are a valid control for unmeasured characteristics that jointly determine mobility and school-level achievement, and new information about the achievement of previous cohorts is a conditionally exogenous shock to parent’s information about school quality.

We find that the public release of information about school-level achievement has a substantial effect on the inter-school mobility of students attending public schools. In general, students are more likely to leave their school when they learn that their schoolmates have performed relatively poorly. Families that speak English at home, particularly those who reside in low-income neighborhoods, respond strongly to early information releases. Once they have absorbed this information, however, they do not respond to subsequent releases. Those who speak a language other than English at home only respond when the information is reframed and given widespread media attention, but their response is large. Arguably, nonEnglish speakers and residents of low-income neighborhoods had the poorest private information about school quality before public information became available, and hence valued the new information most. The delayed response of non-English speakers suggests they face high costs of accessing public information.

\subsection{Previous literature}

A number of studies examine the introduction of new forms of information about school quality in environments where school-level achievement measures are already in the public domain. Figlio and Lucas (2004) and Fiva and Kirkebøen (2008) show that newly-framed measures of school quality affect 
real estate prices, even when a substantial amount of information is already publicly available. Kane et al. (2003) find that real estate prices do not respond to year-to-year fluctuations in a given measure of school quality. These studies suggest that the provision and framing of public information about school quality can influence residential choice (implying an effect on school choice), but this influence is conditioned by the character of the information that is already in the public domain.

Real estate price studies can only provide indirect evidence about school choice decisions, do not capture the effects of information on parents' decisions to enroll their children at non-guaranteed schools, and reveal little about the characteristics of the families whose decisions are affected. Mizala and Urquiola (2008) take a more direct and comprehensive approach, examining the effects of Chile’s highlypublicized SNED awards on school enrollment levels, tuition fees, and school socioeconomic composition. They show that receiving an award had no effect on these outcomes in an environment where measures of school achievement were already widely available.

A related literature finds that providing simplified information about school quality directly to a select group of parents, rather than to the general public, increases the probability that they choose higherachieving schools (Hastings et al. 2007; Hastings and Weinstein 2008). However, public information may have different effects than targeted information strategies: parents may be more likely to act on school quality information when they receive it directly from schools; and newly informed parents, especially those of disadvantaged children, may face less competition for spaces in preferred schools when they are part of a targeted group.

Publicly provided information in the form of "report cards” or rankings like those examined here has been shown to affect consumer decisions in other markets. These markets include health services (Dranove et al. 2003; Dafny and Dranove 2005; Jin and Sorensen 2006) and restaurant patronage (Jin and Leslie 2003). 


\section{$2 \quad$ Institutional Background}

\subsection{School access and funding in B.C.}

School choice opportunities in B.C. are similar to those in many other jurisdictions. Students are guaranteed access to the neighborhood public school whose catchment area they reside in, or they may choose a non-guaranteed neighborhood school, a public magnet program, or a private school. Before 2003, access to a non-guaranteed neighborhood school required the permission of both the guaranteed school and the preferred school. B.C.’s provincial education authority (the Ministry of Education) instituted an official “open boundaries” policy in July 2002 that allows students to attend any public school in the province that has space and facilities available after catchment area students have enrolled. Provincial legislation requires that school boards give priority to students within the district over out-ofdistrict students; boards may elect to give priority to siblings of children who are already enrolled, and must establish policies for allocating priority among students within a priority category. Entry into most magnet programs is restricted to students entering Kindergarten or Grade 1, and space in popular programs is often allocated by lottery.

Districts are not authorized to raise any of their own revenue. The B.C. Ministry of Education provides operating and capital funding directly to public school districts. Operating funds are provided on the basis of total district enrolment. Supplementary funding is provided for each student who is Aboriginal, is gifted or disabled, or who qualifies for English as a Second Language (ESL) instruction. Private schools receive per-student operating grants of 35-50 percent of the base public school rate, and are responsible for teaching the provincial curriculum and meeting various provincial administrative requirements (B.C. Ministry of Education 2005). 


\subsection{Testing and information}

Since the 1999/2000 school year, all public and provincially-funded private schools have been required to administer standardized Foundation Skills Assessment (FSA) exams to students in Grades 4 and 7 in May of each year. Students are examined in Reading Comprehension, Writing, and Numeracy. The FSA exams do not contribute to students’ academic records and play no role in grade completion, and there are no financial incentives for teachers or schools related to student performance. ${ }^{5}$

The Ministry of Education first provided individual and provincial-, district-, and school-level FSA exam results to schools in fall 2000, and instructed them to share the information with parents upon request (B.C. Ministry of Education 2000). The results of the 1999/2000 and 2000/2001 FSA exams were first posted on the Ministry’s website in October 2001 (B.C. Ministry of Education 2001), and each subsequent set of FSA results has been posted the following fall. Beginning in 2003, schools were required to share individual students' exam results with parents before September 30 of each school year.

The Fraser Institute, an independent research and educational organization (Fraser Institute 2008), ${ }^{6}$ began issuing annual “report cards” on B.C.’s elementary schools in June 2003 (Cowley and Easton 2003). These reports include school scores constructed by the Fraser Institute from FSA exam results, and

\footnotetext{
${ }^{5}$ Because these exams are low-stakes, schools do not face strong incentives to strategically exclude lowachieving students from the exams. The participation rate is substantially higher than in some U.S. jurisdictions (Friesen et al. 2009).

${ }^{6}$ The authors are not affiliated with the Fraser Institute in any way.
} 
rankings based on these scores. ${ }^{7}$ From the outset, the Fraser Institute's school report cards have received widespread media coverage in the province’s print, radio and television media. ${ }^{8}$

\section{$3 \quad$ Empirical methodology}

School choice decisions are linked to decisions about residential location because of commuting costs and because access to some public schools is rationed through residential catchment areas. For tractability and because of data limitations, we treat residential location as exogenous and examine inter-school mobility conditional on residential choice.

\subsection{School choice}

We assume that in each school year $t$, parents choose a single school for their child (we do not observe within-year school mobility) from a set of $S_{i t}$ schools. $^{9}$ Suppose the parents of child $i$ have preferences over schools represented by the expected utility function:

$$
U_{i s t}=U\left(q_{s t}, x_{i t} ; \theta\right)
$$

where $q_{s t}$ is the parents' point estimate of school quality, $x_{i t}$ is a vector of individual characteristics that influence preferences, and $\theta$ is a parameter vector.

\footnotetext{
${ }^{7}$ The scores released in 2003 were based on school-average exam results in reading, writing and numeracy in Grades 4 and 7 (six mean scores, each given a weight of 13.3 percent), and the average gap between male and female scores on the Grade 7 reading and numeracy exams (each with a weight of 10 percent). The formula used to produce the scores released in 2004 placed a smaller weight on each of the school-average exam results (8.3 percent instead of 13.3 percent), placed the same weight on the gender gap in Grade 7 reading and numeracy scores (10 percent each) and included the percentage of students that did not "meet expectations" according to provincial standards, with a weight of 30 percent (see Cowley and Easton 2008:96 for details).

${ }^{8}$ A ProQuest search of Vancouver's two most widely-read daily newspapers (the Vancouver Sun and the Province) returned twelve articles (including editorial content) published about the Fraser Institute's first elementary school report cards in June, 2003.

${ }^{9}$ The set of available schools varies across students and time because access to some schools may be restricted to those living within the school's catchment area, principals sometimes exercise discretion over admission of out-of-catchment area students, access to magnet programs may be rationed, access rules changed during our sample window, and because of school openings and closings.
} 
At the completion of each grade, parents evaluate the expected utility of all schools in the choice set. A student currently attending school $s^{\prime}$ will change schools if there is another school $s \in S_{i t}$ that yields enough utility to compensate for the cost of changing schools, $c_{i s t}$. The probability that student $i$ separates from school $s^{\prime}$ at the end of school year $t$ and enrolls in a different school is therefore

$$
\operatorname{Pr}(\text { separate })=1-\prod_{s \in S_{i t}} \operatorname{Pr}\left(U_{i s t}-c_{i s t}<U_{i s^{\prime} t}\right) .
$$

To illustrate how new information about school quality affects school choice decisions, suppose parents' expected utility is linear in characteristics:

$$
U_{i s t}=q_{s t}^{\prime} \pi_{i t}+x_{i t}^{\prime} \beta+u_{i s t}
$$

where $\pi_{i t}$ is a utility weight on expected school quality that may depend on parent and child characteristics, $\beta$ is a vector of preference parameters, and $u_{\text {ist }}$ is a random component.

New information about school-level achievement may change how parents weight different school characteristics when forming expectations of school quality. ${ }^{10}$ Consider the introduction of a new measure of school-level achievement, such as a school report card based on achievement of the previous year's cohort, $r_{\text {st-1 }}$. If we assume that parents' conditional expectation of school quality is based on a linear function of school characteristics, their point estimate of school quality before observing $r_{s t-1}$ is:

$$
q_{s t}^{0}=z_{s t}^{\prime} \delta^{0}+\omega_{s t}^{\prime} \eta^{0}
$$

where $z_{s t}$ is a vector of observable characteristics of school $s$ in year $t, \omega_{s t}$ is a vector of school characteristics observed by parents but not the econometrician, and $\delta^{0}$ and $\eta^{0}$ are weights that parents apply to school characteristics. When parents receive new information about school-level achievement, they revise their beliefs about school quality via the updated conditional expectation:

$$
q_{s t}^{1}=z_{s t}^{\prime} \delta^{1}+\omega_{s t}^{\prime} \eta^{1}+r_{s t-1} \phi^{1}
$$

\footnotetext{
${ }^{10}$ Jin and Sorensen (2006) make this point in the context of information about health care plans.
} 
where $\delta^{1}$ and $\eta^{1}$ are the new weights applied to previously observed school characteristics, and $\phi^{1}$ is the weight they place on the new information. ${ }^{11}$

Given the linear specification of expected utility in eq. (3), parents' expected utility before and after the introduction of the new measure of school-level achievement is:

$$
\begin{aligned}
& U_{i s t}^{0}=z_{s t}^{\prime} \delta^{0} \pi_{i t}+\omega_{s t}^{\prime} \eta^{0} \pi_{i t}+x_{i t}^{\prime} \beta+u_{i s t} \\
& U_{i s t}^{1}=z_{s t}^{\prime} \delta^{1} \pi_{i t}+\omega_{s t}^{\prime} \eta^{1} \pi_{i t}+r_{s t-1} \phi^{1} \pi_{i t}+x_{i t}^{\prime} \beta+u_{i s t} .
\end{aligned}
$$

Combining eqs. (2) and (6), we see that new information not only changes the weights applied to school characteristics in parents' utility, but also changes the weights applied to these characteristics in the probability that students change schools. Similar revisions to these weights occur each time parents receive new signals of school quality.

\subsection{Empirical specification}

We focus on parents' decision to change the school at which their child is enrolled in response to new information about school-level achievement, taking their residential location and current school as given. ${ }^{12}$ We specify a linear probability model for the probability that student $i$ changes school between grades 4 and 5 (at the end of school year $t$ ). In keeping with the above model of school choice, our regression model controls for individual characteristics $\left(x_{i t}\right)$, measured and unmeasured school

\footnotetext{
${ }^{11}$ For example, suppose parents' prior beliefs over true school quality are normally distributed with mean $q_{s t}^{0}$ and precision $p^{0}$, and $r_{s t-1}$ is normally distributed around true school quality with precision $p_{r}$. If parents update their beliefs about school quality using Bayes' rule, their posterior beliefs after observing the signal $r_{\text {st- } 1}$ are normally distributed with mean given by eq. (5), where $\delta^{1}=\delta^{0} p^{0}\left(p^{0}+p_{\mathrm{r}}\right)^{-1}, \eta^{1}=\eta^{0} p^{0}\left(p^{0}\right.$ $\left.+p_{\mathrm{r}}\right)^{-1}$, and $\phi^{1}=p_{\mathrm{r}}\left(p^{0}+p_{\mathrm{r}}\right)^{-1}$.

${ }^{12}$ An alternative approach suggested by our simple theoretical model would be to specify a probability distribution for $u_{i s t}$, e.g., an extreme value distribution, and model school choice in a random utility framework akin to McFadden (1978) or Berry et al. (1995). Since school choice and residential location are likely to be jointly determined, and since we lack data on other determinants of residential choice (e.g., employment, home prices, and family structure), we do not take this approach.
} 
characteristics ( $z_{s t}$ and $\omega_{s t}$, respectively), measures of school-level achievement observed by parents ( $r_{s t-1}$, based on previous student cohorts), and measures of the cost of changing schools $\left(c_{i s t}\right)$.

Because new information changes the weights that parents give school characteristics in school choice decisions, our specification of students' separation probability allows coefficients on these characteristics to vary across three information “regimes.” During the first regime (1999/2000), parents observed no formal measures of school-level achievement. Parents could observe school-average FSA exam results during the second regime (2000/2001 and 2001/2002), and they could observe both school-average FSA exam results and the Fraser Institute scores and rankings during the third regime (2002/2003 and 2003/2004).

Given the above, our linear probability model of school separations is:

$$
\begin{gathered}
y_{i t}=x_{i t}^{\prime} \beta+z_{s t}^{\prime}\left(\delta_{i t}^{1}+\delta_{i t}^{2} d_{t}^{2}+\delta_{i t}^{3} d_{t}^{3}\right)+r_{s t-1}^{\prime}\left(\phi_{i t} n_{t}+\phi_{i t}^{+} n_{t}^{+}\right)+ \\
\omega_{s t}^{\prime}\left(\eta_{i t}^{1}+\eta_{i t}^{2} d_{t}^{2}+\eta_{i t}^{3} d_{t}^{3}\right)+c_{i s t}^{\prime} \lambda+\varepsilon_{i s t}
\end{gathered}
$$

where $y_{i t}$ is a binary variable indicating whether student $i$ separates from their school at the end of the school year, $n_{t}$ is an indicator for the first year in which a measure of school-level achievement is available to parents ("news"); $n_{t}^{+}$is an indicator for subsequent years in which the measure remains in the public domain (“old news"); $d_{t}^{2}$ and $d_{t}^{3}$ are indicator variables for the second and third information regimes, respectively; $\beta, \phi, \phi^{+}, \delta_{i t}^{1}, \delta_{i t}^{2}, \delta_{i t}^{3}, \eta_{i t}^{1}, \eta_{i t}^{2}, \eta_{i t}^{3}$ and $\lambda$ are parameters to be estimated; and $\varepsilon_{i s t}$ is a stochastic error term. We assume the following specification for unmeasured school characteristics:

$$
\omega_{s t}=\tau_{t}+\zeta_{s}+v_{s t}
$$


where $\tau_{t}$ is a fixed year effect; $\zeta_{s}$ is a fixed school effect that captures the role of unobserved timeinvariant school characteristics; and $v_{\text {st }}$ is a random school-by-year effect that captures any additional unmeasured correlation among students’ separation behavior in a given school and year. ${ }^{13}$

\subsection{Identification}

School-level information measures that are based on the previous cohort's achievement are exogenous in the separation equation if there is no persistence in school-by-year level shocks that jointly affect achievement and separations (e.g. changes to a school's teacher complement). However, if these shocks are persistent, then previous cohorts' achievement will be correlated with unmeasured heterogeneity in separations in the current school year, $v_{s t}$. This will bias the estimated effect of information about previous cohorts’ performance on separations: $\phi$ and $\phi^{+}$will measure the response to information and the persistent effect of previous years’ shocks that jointly affect achievement and separations.

We eliminate this bias by adding a control for the current cohort's measured achievement, $r_{s t}$, in the separation equation (7). Note that $r_{s t}$ contains all relevant information about the persistent component of previous years' shocks insofar as it affects the current cohort's achievement. That is, previous cohorts' achievement is conditionally exogenous in the separation equation, given the current cohort's achievement, under the assumption that previous years' shocks are only correlated with $v_{s t}$ via their persistent effect on achievement. ${ }^{14,15}$

\footnotetext{
${ }^{13}$ Stated differently, our reported standard errors account for clustering at the school-by-year level. ${ }^{14} \mathrm{We}$ formalize the argument as follows. Suppose average achievement at school $s$ in year $t$ is a meanzero function of observables, a school-specific component, a year-specific component, and a mean-zero school-by-year shock, $\chi_{s t}$, that is uncorrelated with other inputs to achievement. That is, $r_{s t}=r\left(z_{s t}, s, t\right)+$ $\chi_{s t}$. Current-year achievement is endogenous in the separation equation if $\chi_{s t}$ is correlated with unmeasured heterogeneity in separations, $v_{s t}$. We can represent this correlation by $v_{s t}=\kappa \chi_{s t}+\xi_{s t}$ where $\xi_{s t}$ is a meanzero component orthogonal to $\chi_{s t}$. If the shocks are not persistent, so that $\mathrm{E}\left[\chi_{s t-1} \chi_{s t}\right]=0$, and the previous year's shock to achievement has no direct correlation with school-by-year heterogeneity in separations, so that $\mathrm{E}\left[\chi_{s t-1} \xi_{s t}\right]=0$, then $r_{s t-1}$ is exogenous in the separation equation because $\mathrm{E}\left[\chi_{s t-1} v_{s t}\right]=0$. Suppose to the contrary that shocks exhibit some persistence. We can represent this by $\chi_{s t}=\rho \chi_{s t-1}+\varsigma_{s t}$ where $\varsigma_{s t}$ has mean zero and is orthogonal to $\chi_{\text {st-1. }}$. Even if the previous year's shock has no direct correlation with current-
} 
The relationship between the current cohort's measured achievement and separations may have been

affected by the introduction of open enrolment. If parents at low-achieving schools were more

constrained by neighborhood enrolment policies than parents in high-achieving schools, then 2002/03

separations from schools with low current achievement might have increased relative to separations from

schools with high current achievement, even if information released in the same year had no effect on

parents' decisions. To account for the potentially confounding effect of this policy change, we therefore

allow the effect of $r_{\text {st }}$ to differ before and after the introduction of open boundaries. Under our

maintained assumption that previous years' shocks are only correlated with $v_{s t}$ via their persistent effect

on achievement, this identifies the effect of information released in 2002/03 separately from the effect of the change in enrolment policy. ${ }^{16}$

\subsection{Data}

year heterogeneity in separations (that is, $\mathrm{E}\left[\chi_{s t-1} \xi_{s t}\right]=0$ ), the previous cohort's achievement is now endogenous in the separation equation: $E\left[\chi_{s t-1} v_{s t}\right]=\kappa \rho \operatorname{Var}\left(\chi_{s t-1}\right) \neq 0$. However, conditional on the current cohort's achievement, if $\mathrm{E}\left[\chi_{\text {st }-1} \xi_{s t} \mid \chi_{s t}\right]=0$ then the previous cohort's achievement is exogenous: $\mathrm{E}\left[\chi_{s t-1} v_{s t} \mid\right.$ $\left.\chi_{s t}\right]=0$. So our identifying assumption is that, conditional on the current cohort's achievement, previous years' shocks to achievement are only correlated with current-year unmeasured heterogeneity in separations via their persistent effect on achievement; that is, $E\left[\chi_{s t-1} \xi_{s t} \mid \chi_{s t}\right]=0$.

${ }^{15}$ In closely related work, Smith (2009) estimates the relationship between test scores and separations using the same underlying data. Smith's identifying assumption is that the relationship between 1998 test scores and 1999 separations would have held in later periods if not for the release of information.

Unfortunately, the FSA test scores were not administered in 1998. Smith uses (i) imputed 1998 FSA test scores (based on the relationship between observed student characteristics and 1999 FSA scores) and (ii) scores from a different test that was administered in 1998, as proxies for these missing test scores. His method will attribute any differences in the way that these proxies and actual FSA test scores are related to next period's separations to the effects of the release of information.

${ }^{16}$ Our identifying assumption that previous years' shocks to achievement are uncorrelated with $v_{\text {st }}$ conditional on current achievement would be violated in the following scenario: test scores of grade 4 students in $t-1$ (released as information in $t$ ) are influenced by an unusually bad teacher; this teacher is reassigned to teach grade 5 in $t$; the teachers' performance and grade assignment is observed by parents of grade 4 students in $t$; these parents respond by increasing the probability that they move their child to a different school in $t$ in order to avoid this teacher in $t+1$. In this example, the shock to achievement in $t-1$ due to the bad teacher is correlated with $v_{s t}$ because grade 4 parents anticipate that their children will be exposed to this bad teacher in future. Conditioning on current achievement does not account for this correlation because the current grade 4 cohort is not taught by this teacher. We expect that this scenario does not occur frequently enough to raise serious concerns about our identifying assumption. 
Our investigation focuses on B.C.’s Lower Mainland region, a large metropolitan area with a population of approximately 2.5 million that includes the city of Vancouver, its suburbs, and communities that are contiguous with them. It encompasses fourteen public school districts with a total annual enrollment of roughly 375,000 students in Kindergarten through Grade 12 (B.C. Ministry of Education 2007:8). ${ }^{17}$

Our student-level data are based on two administrative databases, integrated via a unique student identifier: an enrollment database (collected for each student on September 30 of each year), and an FSA exam database. We augment these data with several external measures. First, we add school-by-grade average student characteristics. Second, we add selected characteristics of each student's neighborhood as measured in the Census of Population. Third, we add geographic coordinates associated with each school's postal code and each student's residential postal code and use them to calculate measures of distance between the student's home and various schools, and to create measures of the availability of school choice in the area surrounding the student's home. We also identify each student's guaranteed school based on their postal code. Details of how we construct these measures are provided in a Data Appendix, available on request. Finally, we add the annual school scores and rankings that are produced and publicized by the Fraser Institute for each school year from 1999/2000 through 2003/04, and a threeyear average score released in 2003.

\subsection{Population under analysis and choice of explanatory variables}

Our analysis is based on an extract of the enrollment database that includes all students in the Lower Mainland who entered Grade 2 between 1996/1997 and 2001/2002. We restrict our sample to public school students who made regular progress through the grades (so that they entered Grades 3, 4, and 5 with their cohort) and remained in the Lower Mainland in Grades 2 through $5 .{ }^{18}$ We restrict our attention

\footnotetext{
${ }^{17}$ The region is geographically isolated from other populated areas by the U.S. border to the south, the Strait of Georgia to the west, and rugged mountains to the north and east.

${ }^{18}$ Our data do not allow us to observe transitions following Grade 4 for students who are held back in one or more years. Very few students accelerate through the grades.
} 
to separation decisions at the end of the Grade 4 year in order to control for students' own performance on the FSA exams as well as the average performance of the student's same-school cohort. We create our indicator of separations, $y_{i t}$, by comparing the school at which the student was enrolled on September 30 of their Grade 4 year and the school at which they were enrolled on September 30 of their Grade 5 year.

Controls for individual characteristics include the student's own FSA exam scores in reading and numeracy, an indicator of whether the student previously separated from their school following Grades 2 and/or 3, and indicators for gender, Aboriginal identity, language spoken at home (Chinese, Punjabi, any other language besides English), disability, giftedness, and ESL status. We do not directly observe any socioeconomic characteristics of students' families. Therefore we include as proxies for unobserved student background characteristics a set of socioeconomic characteristics of the Census Enumeration or Dissemination Area (EA or DA, respectively) in which the student resides. ${ }^{19}$ Controls for school characteristics include the proportion of Grade 4 students who are Aboriginal, speak Chinese at home, speak Punjabi at home, speak another non-English language at home, have special needs (gifted or disabled), or are in an ESL program.

We include several proxies for students' cost of changing schools. First, we include an indicator for attending a non-guaranteed public school, and for attending a French Immersion program (because this program is offered in a limited set of schools). ${ }^{20}$ Second, we include the distance from the student's home

\footnotetext{
${ }^{19}$ Specifically, we include the proportion of household heads in the EA/DA who immigrated to Canada in the previous five years, whose education level was less than grade 9, without a high school diploma, with a high school diploma, and with a bachelor's degree or higher (the omitted category is those with more than high school but less than a bachelor's degree), and the proportion whose incomes were below the low-income cutoff defined by Statistics Canada. See the Data Appendix for more information on how we construct these measures.

${ }^{20}$ French Immersion programs, which developed across Canada in the 1970's as part of a national effort to encourage bilingualism, are the most popular form of magnet programs in the Lower Mainland. They provide French-only instruction to non-francophone students from Kindergarten through Grade 5, when English language instruction is introduced in some subjects.
} 
to the school attended and to the guaranteed school. ${ }^{21}$ Third, we control for the density of choice alternatives near the student's home: the number of public and private schools within the $75^{\text {th }}$ percentile of travel distance to public and private schools in our sample (1.06 km and $6.52 \mathrm{~km}$, respectively). ${ }^{22}$

Each measure of school-level achievement released during our sample window enters our regression model interacted with an indicator for the year in which it became available to parents ("news"), and interacted with an indicator for subsequent years that this information remained in the public domain (“old news”). The complete set of information shocks and the variables we use to capture them in our empirical model are summarized in Table 1. The first set of FSA results was released by the Ministry in the second year of our data, and a new set was released in each subsequent year. The Fraser Institute released their first scores and rankings in June 2003, based on the FSA exams written in 1999/2000, 2000/2001 and 2001/2002. The release included overall scores (out of 10) for each school in each of the three years, the three-year average score (also out of 10), and school rankings based on the 2001/2002 score and the three-year average score. ${ }^{23}$ Of these, only the scores and rankings for 2001/2002 and the three-year averages were reported in the media. ${ }^{24}$ We have no way to know (ex ante) how parents aggregated the various measures contained in the first Fraser Institute release. We include the three-year average score and the score based on the 2001/2002 FSA exam, since these measures were published and

\footnotetext{
${ }^{21}$ Both distance measures are based on reported postal codes. We exclude a small number of cases where the distance between a student's home and the school they attend exceeds 50 kilometers, since this probably reflects misreported postal codes.

${ }^{22}$ Gibbons, Machin and Silva (2008) point out that measures of this kind are not ideal. However, they show that a number of alternative methods for defining measures of school choice availability produce qualitatively similar results. Likewise, our reported results are not sensitive to the inclusion of these measures, nor are they sensitive to alternate definitions of travel distance.

${ }^{23}$ Our estimation sample includes only students who attended schools for which a full set of Fraser Institute scores was released in both 2003 and 2004. Some schools were excluded from the Fraser Institute reports in 2003, 2004 or in both years and, among schools that were included, some did not receive a full set of scores. See the Data Appendix for details.

${ }^{24}$ See, e.g. "Elementary school rankings one useful tool for B.C.," in The Province newspaper, June 8, 2003: pg. A.20. Also "Elementary schools get their grades, by Janet Steffenhagen in The Vancouver Sun newspaper, June 9, 2003: pg. B.1.
} 
were also the basis of the published rankings. ${ }^{25}$ The Fraser Institute released an additional set of scores and rankings based on the 2002/2003 FSA exams in spring 2004.

We account for the possibility that the open boundaries policy changed the relationship between schoollevel achievement and separations by allowing the effect of the current cohort's measured achievement $\left(r_{s t}\right)$ to differ before and after the introduction of open boundaries. All of our specifications include the average FSA reading and numeracy exam results of the school's current Grade 4 cohort, and their interactions with a binary variable that indicates whether the open boundaries policy was in effect. Under our assumption that previous years' shocks are correlated with $v_{\text {st }}$ only via their persistent effect on achievement, the effects of new information about school-level achievement received in 2002/03 are identified separately from the effect of the change in enrolment policies in the same year. We note that the estimated effects of news and old news in 2001 and earlier measure parents' school choice response to new information under the neighborhood enrolment policy, while the estimated effects of news and old news measures after 2001 measure the response to information under the open enrolment policy.

\section{$4 \quad$ Results}

\subsection{Descriptive statistics}

Our estimation sample consists of 74,368 Grade 4 students. ${ }^{26}$ We report sample means and mean separation rates for some key characteristics in Table 2 (sample means for all control variables are reported in Appendix Table A1, available on request). Five percent of students self-report as Aboriginal; these students have significantly higher separation rates than average (19.6\% vs. 9.3\%). Almost one-third of students speak a language at home other than English, and overall these students have a higher than

\footnotetext{
${ }^{25}$ To assess the robustness of this assumption, we also report results that control for the three-year average ranking and 2001/2002 ranking. In additional robustness checks (not reported) we control for all three scores and rankings and obtain results very similar to those reported here, although we lose some precision due to the high correlation between the scores/rankings in the three years (see Appendix Table A2).

${ }^{26}$ Students with missing data are excluded. See the Data Appendix for information about the nature and frequency of missing data.
} 
average separation rate. However, non-English language students are a very diverse group. The two most common home language groups are "Chinese” (13.5 percent) and Punjabi (8.1 percent). The separation rate of Chinese language students is below average (8.4\%); the separation rate of Punjabi language students is above average (10.1\%). The remaining non-English language students have a substantially higher separation rate (13.5\%).

Of the 362 public elementary schools in our sample, 356 are neighborhood (catchment area) schools and 6 are magnet schools that draw from a broad set of students within or across school districts. ${ }^{27}$ Approximately 76 percent of students attend their guaranteed school. A further 6.5 percent of students attend a French Immersion program, and the remaining 17.5 percent of students attend a non-guaranteed neighborhood school. Students who attend their guaranteed school have below-average separation rates (8.7\% vs. 9.3\%), and the separation rates of French Immersion students are even lower (6.5\%).

Table 3 summarizes the joint distribution of school achievement measures that enter our baseline specification. Appendix Table A2, available on request, presents similar information for the complete set of achievement measures. The school-average FSA results trend upward over time; the trend in the Fraser Institute scores is less pronounced. Successive releases of school-average FSA results vary substantially from year to year: the average correlation between FSA results in adjacent years is 0.65 . The Fraser Institute scores exhibit more persistence: the correlation between the 2001/2002 and 2002/2003 scores is about 0.72 . The contemporaneous correlation between school-average FSA results and Fraser Institute scores is roughly 0.8 .

\footnotetext{
${ }^{27}$ Magnet programs are often housed within schools that also serve catchment areas; we define magnet schools as schools that house magnet programs only.
} 


\subsection{Econometric estimates}

We present our baseline estimates of the effect of information on school separations in Table 4. Our baseline model includes school-average FSA exam results based on the average of the reading and numeracy mean scores, and Fraser Institute scores. The model includes fixed school effects, so that identification is based on how different cohorts of students in the same school respond to different information about previous cohorts' performance, conditional on characteristics and their own cohort's performance. Appendix Table A3, available on request, reports the estimated coefficients on all control variables.

We begin by discussing estimates in the first column of Table 4 . There is no evidence of any systematic overall response to publicly-released FSA exam scores. Coefficient estimates for the first two releases of FSA scores are negative, indicating that students' separation probability declined at public schools that received better news (higher school-average exam results), relative to public schools where the news was worse. However, only the second release is (marginally) statistically significant. Estimated coefficients on the Fraser Institute scores indicate a similar pattern of response. However, these coefficients are difficult to interpret given the high degree of collinearity between the Fraser Institute scores and FSA results released in the same year.

Thus we prefer the estimates in column 2, where we restrict the specification to a single information measure in each year: FSA exam scores in the first two years (when these were the only information measures available) and Fraser Institute scores in the latter two years (since these were published in the media, and therefore more salient). The pattern of parents' response to information is now clearer, but remains weak. In each case, coefficient estimates are negative, indicating that students' separation probability declined at schools where the news was better; and symmetrically, that separations increased at schools where the news was worse. Only the response to the second release of FSA scores and the second release of Fraser Institute scores is statistically significant, however. None of the information 
shocks had any effect beyond their immediate impact in the year in which they were released: the estimated "old news" effects are all statistically insignificant, and the point estimates are small.

Coefficients on the current-year mean FSA score and its' interaction with an indicator for those years that the open enrolment policy was in effect are small and statistically insignificant, indicating no systematic relationship between current-year achievement and separations either before or after the introduction of open enrolment. The sign of the point estimate on the interaction term is positive, suggesting that, if anything, open enrolment increased separations from good schools relative to bad schools. Thus we are confident that any estimated effects of the first Fraser Institute shock, which coincided with the introduction of open enrolment, capture parents' response to the introduction of the Fraser Institute report cards, and not unobserved heterogeneity that jointly affects achievement and mobility, or changes in behavior associated with the introduction of open enrolment. Furthermore, the statistically significant response to the second release of school-average FSA scores by the Ministry in 2001, which predates the introduction of the open boundaries policy, reinforces the impression that the open boundaries policy may have had little effect on parents' school choice decisions. Some parents were evidently able to respond to new information about school-level achievement even absent official open enrolment policies.

Estimates in column 2 mask considerable heterogeneity in parents' response to information, however. In columns 3 and 4, we divide the sample into students who report speaking English at home and those who report speaking another language. Language barriers may increase some parents’ cost of accessing information. Moreover, home language may act as a proxy for preferences or cultural norms. We find that parents of children who speak English at home responded strongly to the first two releases of FSA exam scores. In each case, the magnitude of the point estimate implies that when a school scored one standard deviation higher in the distribution of published school-average FSA scores, students' separation probability declined by slightly more than one percentage point. On a base separation rate of about $9 \%$ per year, this is quite a large response. However, these parents did not respond to subsequent information 
releases by the Fraser Institute, indicating they had already absorbed the available information about school achievement.

In contrast, parents of children who report speaking a language other than English at home did not respond to the release of FSA scores, but did respond strongly to the second release of Fraser Institute scores. The point estimate implies that a one standard deviation increase in the Fraser Institute score relative to other schools reduced these students' separation probability by 2.4 percentage points. Such a large response suggests poor access to previously released information, rather than resources or preferences, explains these parents’ delayed response to information about school-level achievement.

In columns 5 and 6, we break out the two largest groups of students who report speaking a language other than English at home. The pattern of response is similar. Chinese-speaking parents do not respond to either release of FSA scores, but respond strongly to both releases by the Fraser Institute. Here, the point estimates are large and precisely estimated: a one standard deviation increase in news about a school's first Fraser Institute report card reduced the probability of separation by 3.6 percentage points, and by 4.7 percentage points for the second release. This is an enormous response considering that the mean separation rate among these students was only $8.4 \% .{ }^{28}$ Punjabi-speaking parents respond only to the second Fraser Institute report card, but again the magnitude is large: a one standard deviation increase in the Fraser Institute score reduced these students’ separation probability by 2.7 percentage points.

\footnotetext{
${ }^{28}$ Our estimates of Chinese parents' response to the first Fraser Institute shock will be confounded with their response to the introduction of open boundaries only if our identifying assumption, that previous years' shocks to achievement are only correlated with separations via their persistent effect on achievement, is violated. In the scenario described earlier (in footnote 12), parents wishing to avoid a teacher who had adversely affected grade 4 achievement in $t-1$ and who was assigned to teach a higher grade in $t$ would be more likely to separate. To the extent that some grade 4 parents find themselves in an analogous situation, the separation rate would increase in 2002/03 when school choice became less constrained. In our specification, this increase would be attributed to the effects of the first Fraser Institute shock. However, we think it very unlikely that many parents found themselves in this situation, and even more unlikely that only Chinese parents did so.
} 
A concern is that we may not be measuring heterogeneity in responses due to language barriers, but rather heterogeneity driven by correlates of language such as income. Parents who live in disadvantaged communities may have relatively poor access to information or school choice opportunities. In Table 5, we reproduce estimates for all students, English-speakers, and non-English-speakers, broken out by neighborhood income. Specifically, we break out families who reside in Census EA/DAs in the top (richest) and bottom quartiles of the distribution of average household income. Overall, parents who live in bottom quartile neighborhoods are substantially more responsive to new information than parents in top quartile neighborhoods (columns 1 and 2). The same is true among English-speakers (columns 3 and 4). The relatively strong response among parents who reside in low-income neighborhoods suggests that many are interested in enrolling their children in high-quality schools and have the means to do so, but have relatively poor access to private information about school quality. Their very strong response to the first release of public information indicates it contained substantial news for these parents, leading them to update their beliefs about school quality and respond substantively. Among non-English-speakers, in

contrast, there is no apparent difference in response across neighborhood income quartiles (columns 5 and 6). This again supports the view that language barriers are the underlying cause of these parents' delayed response to information about school-level achievement, rather than constraints imposed by neighborhood enrolment policies prior to 2002. Overall, it seems clear that access to information, rather than school choice opportunities or financial resources, is the essential factor determining how parents respond.

\section{Robustness}

Table 6 explores the sensitivity of our results to sample composition and specification. The first column presents our baseline estimates for English-language parents, reproduced from the third column of Table 4. Results in the second and third columns of Table 4 show that English-language parents' response to the first information shock is not driven by Aboriginal parents or parents of French Immersion students. Both of these groups had unconditional separation rates significantly different from the average student (see Table 2). The response to the second information shock is right on the threshold of statistical significance 
at the $10 \%$ level in our baseline results; excluding either aboriginal students or French Immersion students changes point estimates only slightly, but enough to move the p-value over the $10 \%$ threshold. Results for the Fraser Institute scores are unchanged.

The second panel of Table 6 presents results when we include information measures based on the Fraser Institute school rankings instead of the Fraser Institute school scores out of ten, for each of our home language groups. ${ }^{29}$ The response of English language parents to the second release of FSA scores is no longer statistically significant. The sign of the response of Punjabi language parents to the second Fraser Institute remains unchanged, but the coefficient is no longer statistically significant. ${ }^{30}$

We also examine whether our estimates for separate quartiles of the distribution of neighborhood income and home language group are sensitive to including the Fraser Institute rankings instead of scores. These estimates are in Table 7. Only one result is sensitive to which Fraser Institute measure is used: the effect of the first Fraser Institute release on English language parents in the bottom quartile is statistically significant at the $10 \%$ level when we include the Fraser Institute scores (see Table 5), but is statistically insignificant when we include the Fraser Institute ranking.

Finally, under our identifying assumption, the estimated relationships between our information measures and separations have a causal interpretation. Doubt would be cast on the validity of this assumption if we found similar relationships between separations and test scores that parents could not observe at the time

\footnotetext{
${ }^{29}$ Coefficient estimates for the rankings and school scores have opposing signs, because a smaller rank indicates better performance (the top-ranked school is ranked 1).

${ }^{30}$ In separate results not reported in this paper, we investigate the robustness of our results for English and non-English language parents to alternate information measures based on FSA exam results. We find that including school mean results based on both reading and numeracy scores, instead of their average, or including either one but not the other, leaves the estimated response to the Fraser Institute scores virtually unchanged. When the numeracy score is include alone, the effect of the second information shock on separations of English language students is not statistically significant. All other results are similar to those reported.
} 
of their separation decisions. We implement two falsification tests in which we re-estimate the specifications reported in Table 4, but where we replace the information measures (which are based on year $t-1$ test scores) with measures based on test scores from years $t$ and $t+1$ respectively. Our results, available on request, provide no evidence of any systematic relationships between separations and contemporaneous or future test scores that would cast doubt on our identifying assumption. ${ }^{31}$

\section{$5 \quad$ Conclusion}

We find that the public release of information about school-level achievement had a large effect on the inter-school mobility of some Grade 4 students attending public schools in the Lower Mainland region of B.C. A substantial proportion of parents appear to revise their beliefs about the relative quality of their child's school in response to this information, and "vote with their feet" by moving their child to a preferred school. This response is particularly large among English-language parents who reside in lowincome neighborhoods, and occurs the first time that school-level achievement measures are placed in the public domain. Non-English language parents in both high- and low-income neighborhoods also respond strongly to public information about school quality. However, these parents appear to face higher costs of accessing school quality information disseminated through public media. Chinese language parents, in particular, respond strongly to school quality information only when the media provided widespread

\footnotetext{
${ }^{31}$ Specifically, we estimate two alternative specifications of each of the models reported in Table 4. In the first case, we replace our "news" variables with measures based on year $t+1$ test scores, and correspondingly update the "oldnews" variables. We find no statistically significant response to any of the false "news" measures. We do find occasional statistically significant responses to false "oldnews" measures. The latter is not surprising since the estimated response to "oldnews" in this specification will pick up any true relationship between separations and contemporaneous or lagged achievement. In the second case, we replace our "news" variables with measures based on contemporaneous test scores, and correspondingly update the "oldnews" variables. As discussed in footnote 14, we expect a systematic relationship between contemporaneous achievement and separations if there are unobserved school-level shocks that affect both. Our identifying assumption requires that this relationship is constant over time. If the true relationship between current test scores and separations is time-varying, then controlling for current test scores is insufficient to identify parents' responses to news. Rather, our measured responses to "news" might reflect idiosyncratic shocks to the relationship between school-level achievement and separations that coincide with information releases. However, when we replace our "news" variables with measures based on contemporaneous test scores, we find no systematic year-to-year variation in their coefficients. In the few instances where they are statistically significant, the timing and/or sign of the effects differ from the patterns of "news" responses reported in Table 4.
} 
coverage to the Fraser Institute's school report cards. Although this media attention coincided with the introduction of open enrolment, our identification strategy makes it highly unlikely that the pattern of their responses reflects variation over time in school choice opportunities rather than improved access to information. Since school choice opportunities may vary systematically across neighborhood types, evidence that Chinese language parents responded the same way to the Fraser Institute report cards in high- and low-income neighborhoods supports this view. These results suggest that high-profile dissemination can play a crucial role in ensuring access to publicly-provided information in environments with culturally and linguistically diverse populations.

Jurisdictions that publicize school-level results typically update this information annually, raising concerns that parents may respond to year-to-year fluctuations that are largely noise (Kane and Staiger 2002; Mizala, Romaguera and Urquiola 2007). Our results mitigate these concerns. English-speaking parents absorb information quickly. Subsequent releases, even when the information is reframed, do not generate an additional response. The delayed response of other language groups suggests that annual releases of school quality information that elicit ongoing media coverage may play an important role in communicating that information to all segments of the community, including recent immigrants.

These results add to a growing body of evidence that information about school-level achievement affects behavior in ways that may have real consequences for educational outcomes. In addition to ensuring that all parents are able to access the information provided, educational authorities should therefore take care to ensure that widely disseminated information brings competitive pressure to bear on schools that are ineffective, rather than on schools that serve disadvantaged populations. As a growing literature attests, designing meaningful measures of school effectiveness continues to be a challenge (Hægeland et al. 2004; Mizala, Romaguera and Urquiola 2007). 


\section{References}

Becker, G. S. (1995). Human capital and poverty alleviation, World Bank Human Resource and Operation Policy Working Paper Number 52. Washington, D.C.

Berry, Steven, James Levinsohn and Ariel Pakes (1995). Automobile prices in market equilibrium, Econometrica 63(4): 841-890.

B.C. Ministry of Education (1999). English as a Second Language Policy Framework. http://www.bced.gov.bc.ca/esl/policy/framework.pdf.

B.C. Ministry of Education (2002). 2002/03 Operating Grants Manual to British Columbia School Boards. http://www.bced.gov.bc.ca/k12funding/funding/02-03/estimates/operating-grants-manual.pdf

B.C. Ministry of Education (2000). Interpreting and communicating Foundation Skills Assessment Results 2000. http://www.bced.gov.bc.ca/assessment/fsa/pdfs/00interpret.pdf.

B.C. Ministry of Education (2001). Interpreting and communicating Foundation Skills Assessment Results 2001. http://www.bced.gov.bc.ca/assessment/fsa/pdfs/01interpret.pdf

B.C. Ministry of Education (2005). Overview of Independent Schools in British Columbia. http://www.bced.gov.bc.ca/independentschools/geninfo_05.pdf

B.C. Ministry of Education (2007). 2006/07 Summary of Key Information. http://www.bced.gov.bc.ca/keyinfo/pdfs/ski_plusglossary.pdf

Cowley, Peter (2007). Bringing Education into the Market Place: Part 1 - The Report Cards on Schools. Vancouver, B.C.: The Fraser Institute.

Cowley, Peter and Stephen T. Easton, (2003). Report Card on British Columbia's Elementary Schools: 2003 Edition. Vancouver, B.C.: Fraser Institute.

Cowley, Peter and Stephen T. Easton, (2008). Report Card on British Columbia's Elementary Schools: 2008 Edition. Vancouver, B.C.: Fraser Institute.

Dafny, Leemore and David Dranove (2005). Do report cards tell consumers anything they don't already know? The case of Medicare HMOs. NBER Working Paper No. 11420. National Bureau of Economic Research.

Downes, T.A. and J.E. Zabel (2002). The impact of school characteristics on house prices: Chicago 19871991, Journal of Urban Economics 52(1): 1-25.

Dranove, David, Daniel Kessler, Mark McClellan and Mark Satterthwaite (2003). Is more information better? The effects of "report cards" on health care providers, Journal of Political Economy 111(3): 555588.

Figlio, David N. and Maurice E. Lucas (2004). What's in a grade? School report cards and the housing market, American Economic Review 94(3): 591-604. 
Fiske, E. B., and H. F. Ladd (2000). When Schools Compete: A Cautionary Tale. Washington, DC: Brookings Institution Press.

Fiva, John F. and Lars J. Kirkebøen (2008). Does the housing market react to new information on school quality? CESifo Working Paper No. 2299.

Fraser Institute (2008). Who We Are. http://www.fraserinstitute.org/aboutus/whoweare/.

Friedman, M. (1955). The role of government in education, in Solo, ed., Economics and the Public Interest. Rutgers University Press.

Friesen, Jane, Ross Hickey and Brian Krauth (2009). Disabled peers and academic achievement. Simon Fraser University.

Gibbons, S, S. Machin, S and O. Silva (2008). Competition, choice and pupil achievement, Journal of the European Economic Association, 6(4): 912-947.

Hægeland, Torbjørn, Lars J. Kirkebøen, Oddbjørn Raaum and Kjell G. Salvanes (2004). Marks across lower secondary schools in Norway: What can be explained by the composition of pupils and school resources?, Report 2004/11. Oslo-Kongsvinger: Statistics Norway.

Hanushek, Eric A., Kain, John F., and Rivkin, Steven G. (2002). Inferring program effects for special populations: Does special education raise achievement for students with disabilities? Review of Economics and Statistics, 84: 584-599.

Hasting, J., R. Van Weelden and J. Weinstein (2007). Preferences, information and parental choice behavior in public school choice, NBER Working Paper No.12995. National Bureau of Economic Research.

Hasting, J., and J. Weinstein (2008). Information, school choice and academic achievement: evidence from two experiments, Quarterly Journal of Economics, forthcoming.

Hoxby, Caroline M. (2003). School choice and school productivity (or could school choice be a tide that lifts all boats?, in C. Hoxby, ed., The Economics of School Choice. Chicago: The University of Chicago Press.

Jin, Ginger Zhe and Phillip Leslie (2003). The effects of information on product quality: evidence from restaurant hygiene grade cards, Quarterly Journal of Economics 118(2): 409-451.

Jin, Ginger Zhe and Alan T. Sorensen (2006). Information and consumer choice: the value of publicized health plan ratings, Journal of Health Economics, 25(2): 248-275

Kane, Thomas and Douglas O. Staiger (2002). The promise and pitfalls of using imprecise school accountability measures, Journal of Economic Perspectives 16(4): 91-114.

Kane, Thomas J., Douglas O. Staiger and Gavin Samms (2003). School accountability ratings and housing values, Brookings-Wharton Papers on Urban Affairs: 83-137.

McFadden, Daniel (1978). Modelling the choice of residential location, in eds. Karlquist, A. et al., Spatial Interaction Theory and Planning Models. New York: Elsevier North-Holland. 
Mizala, Alejandra, Pilar Romaguera and Miguel Urquiola (2007). Socioeconomic status or noise?

Tradeoffs in the generation of school quality information, Journal of Development Economics 84: 61-75.

Mizala, Alejandra and Miguel Urquiola (2008). School markets: the impact of information approximating school effectiveness. Working Paper, Columbia University.

Smith, Justin (2009). Learning about school quality: Does new information affect school choice? Unpublished manuscript.

West, Anne and H. Pennell (2000). Publishing school examination results in England: Incentives and consequences, Educational Studies 26(4): 423-436. 


\section{Tables}

Table 1: $\quad$ Information Shocks and Information Variables

\begin{tabular}{|c|c|c|c|}
\hline Information & Date & "News" Variables & "Old News" Variables \\
\hline $\begin{array}{l}\text { 1999/2000 cohort school mean FSA } \\
\text { exam results released to parents on } \\
\text { request }\end{array}$ & Oct. 2000 & $\begin{array}{l}(1999 \text { Mean FSA } \\
\text { Score }) *(Y r=2000)\end{array}$ & $\begin{array}{l}\text { (1999 Mean FSA } \\
\text { Score)*(Yr }>2000)\end{array}$ \\
\hline $\begin{array}{l}\text { 2000/2001 cohort school } \\
\text { mean FSA exam results released on } \\
\text { Ministry of Education website }\end{array}$ & Oct. 2001 & $\begin{array}{l}(2000 \text { Mean FSA } \\
\text { Score })^{*}(\mathrm{Yr}=2001)\end{array}$ & $\begin{array}{l}\text { (2000 Mean FSA } \\
\text { Score)*(Yr>2001) }\end{array}$ \\
\hline $\begin{array}{l}\text { 2001/2002 cohort school } \\
\text { mean FSA exam results released on } \\
\text { Ministry of Education website }\end{array}$ & Oct. 2002 & $\begin{array}{l}\text { (2001 Mean FSA } \\
\text { Score }) *(Y r=2002)\end{array}$ & $\begin{array}{l}\text { (2001 Mean FSA } \\
\text { Score)*(Yr }>2002)\end{array}$ \\
\hline $\begin{array}{l}\text { 1999/2000, 2000/2001 and 2001/2002 } \\
\text { cohort Fraser Institute (FI) scores and } \\
\text { rankings released }\end{array}$ & June 2003 & $\begin{array}{l}(1999-2001 \text { Mean FI } \\
\text { Score })^{*}(\mathrm{Yr}=2002) ; \\
(2001 \mathrm{FI} \text { Score }) *(\mathrm{Yr}=2002)\end{array}$ & $\begin{array}{l}\text { (1999-2001 Mean FI } \\
\text { Score)*(Yr>2002); } \\
(2001 \mathrm{FI} \\
\text { Score }) *(\mathrm{Yr}>2002)\end{array}$ \\
\hline $\begin{array}{l}\text { 2002/2003 cohort school } \\
\text { mean FSA exam results released on } \\
\text { Ministry of Education website }\end{array}$ & Oct. 2003 & $\begin{array}{l}(2002 \text { Mean FSA } \\
\text { Score }) *(Y r=2003)\end{array}$ & out of sample \\
\hline $\begin{array}{l}\text { 2002/2003 cohort Fraser Institute } \\
\text { scores and rankings released }\end{array}$ & June 2004 & $(2002$ FI Score $) *(Y r=2003)$ & out of sample \\
\hline
\end{tabular}

Sources: see text.

Note: Calendar years in "News" and "Old news" variable names refer to the calendar year in which the school year began. For instance, “2001 FI Score” refers to the Fraser Institute score based on the FSA exam administered in the 2001/2002 school year. This measure was released in June 2003, and hence could first affect separations at the end of the 2002/2003 school year $(\mathrm{Yr}=2002)$. 
Table 2: Sample Characteristics, Grade 4 Students Enrolled in Lower Mainland Schools, 1999/2000-2003/2004

\begin{tabular}{|c|c|c|}
\hline & Sample Percent & $\begin{array}{c}\text { School Separation } \\
\text { Rate }\end{array}$ \\
\hline All & 100.0 & 9.3 \\
\hline Aboriginal & 5.0 & 19.6 \\
\hline Non-English home language & 32.6 & 12.8 \\
\hline Chinese home language & 13.5 & 8.4 \\
\hline Punjabi home language & 8.1 & 10.1 \\
\hline Other home language & 14.3 & 13.5 \\
\hline English as a second language & 30.2 & 11.0 \\
\hline Attends guaranteed public school & 75.6 & 8.7 \\
\hline Attends French immersion program & 6.5 & 6.6 \\
\hline
\end{tabular}

Source: Authors' calculations based on B.C. Ministry of Education enrollment database.

Table 3: Distribution of School Achievement Measures, Lower Mainland Public Schools, 1999/20002003/2004

\begin{tabular}{|c|c|c|c|c|c|c|c|c|c|}
\hline & \multirow[b]{3}{*}{ Mean } & \multirow[b]{3}{*}{$\begin{array}{l}\text { Std. } \\
\text { Dev }\end{array}$} & \multicolumn{7}{|c|}{ Correlation } \\
\hline & & & \multicolumn{4}{|c|}{ School-Average FSA Score } & \multicolumn{3}{|c|}{ Fraser Institute Score } \\
\hline & & & $\begin{array}{c}1999 / \\
2000\end{array}$ & $\begin{array}{c}2000 / \\
2001\end{array}$ & $\begin{array}{c}2001 / \\
2002\end{array}$ & $\begin{array}{c}2002 / \\
2003\end{array}$ & $\begin{array}{l}3 \text { Year } \\
\text { Avg. }\end{array}$ & $\begin{array}{c}2001 / \\
2002\end{array}$ & $\begin{array}{c}2002 / \\
2003\end{array}$ \\
\hline \multicolumn{10}{|l|}{ Public Schools } \\
\hline 1999/2000 FSA & -0.125 & 0.345 & 1 & & & & & & \\
\hline 2000/2001 FSA & -0.123 & 0.381 & 0.632 & 1 & & & & & \\
\hline 2001/2002 FSA & 0.094 & 0.318 & 0.608 & 0.628 & 1 & & & & \\
\hline 2002/2003 FSA & 0.116 & 0.325 & 0.526 & 0.575 & 0.667 & 1 & & & \\
\hline 3 Year Avg. FI & 6.56 & 1.44 & 0.750 & 0.758 & 0.783 & 0.666 & 1 & & \\
\hline 2001/2002 FI & 6.59 & 1.56 & 0.599 & 0.610 & 0.810 & 0.618 & 0.886 & 1 & \\
\hline 2002/2003 FI & 6.71 & 1.58 & 0.624 & 0.584 & 0.651 & 0.789 & 0.784 & 0.719 & 1 \\
\hline
\end{tabular}

Source: Authors' calculations based on 362 public schools in B.C. Ministry of Education enrollment database that met our sample restrictions, and published Fraser Institute school scores. Notes: FSA scores are the average of school-average reading scores and school-average numeracy scores. FSA exam results have zero mean and unit variance in the population of B.C. students. The "3 Year Avg.” Fraser Institute score is the average of scores based on the 1999/2000-2001/2002 FSA exams. Fraser Institute scores are measured on a scale between zero and ten. 
Table 4: Effect of Information about School-level Achievement on Separation Probability, Grade 4 Students in Lower Mainland Public Schools, 1999/2000- 2003/2004

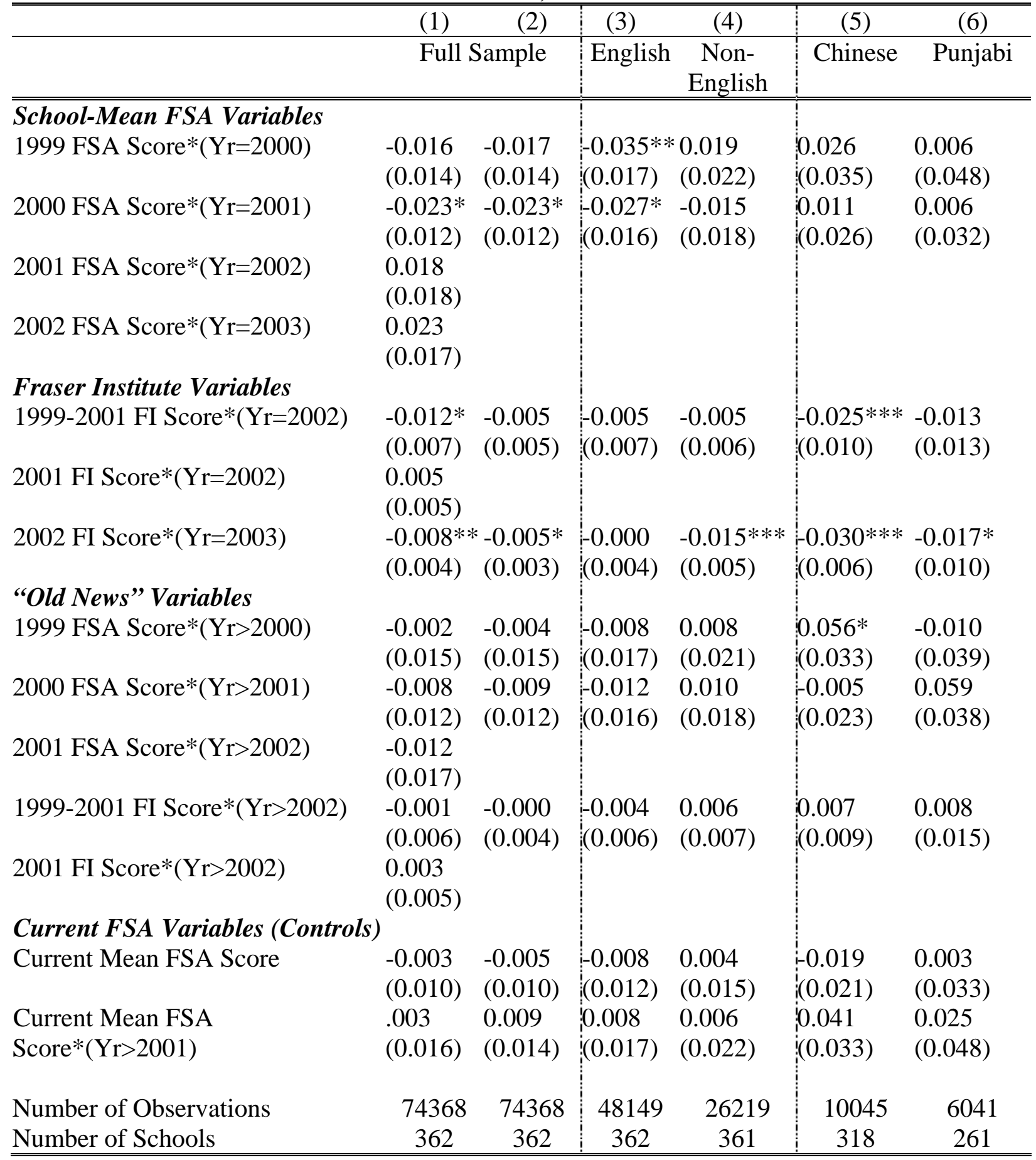

Source: Authors' calculations based on B.C. Ministry of Education enrollment and FSA exam databases.

Notes: Robust standard errors in parentheses, clustered at the school-by-year level. ${ }^{* * *}$ indicates statistically significant at the $1 \%$ level, $* *$ indicates significant at the $5 \%$ level, *indicates significant at the $10 \%$ level. 
Table 5: Effect of Information about School-level Achievement on Separation Probability, by Home Language and Quartile of Distribution of Mean Household Income, Grade 4 Students in Lower Mainland Public Schools, 1999/2000-2003/2004

\begin{tabular}{|c|c|c|c|c|c|c|}
\hline & \multicolumn{2}{|c|}{ All } & \multicolumn{2}{|c|}{ English } & \multicolumn{2}{|c|}{ Non-English } \\
\hline & $\begin{array}{c}\text { (1) } \\
\text { Top } \\
\text { Quartile }\end{array}$ & $\begin{array}{c}(2) \\
\text { Bottom } \\
\text { Quartile }\end{array}$ & $\begin{array}{c}\text { (3) } \\
\text { Top } \\
\text { Quartile }\end{array}$ & $\begin{array}{c}(4) \\
\text { Bottom } \\
\text { Quartile }\end{array}$ & $\begin{array}{c}\text { (5) } \\
\text { Top } \\
\text { Quartile }\end{array}$ & $\begin{array}{c}(6) \\
\text { Bottom } \\
\text { Quartile }\end{array}$ \\
\hline \multicolumn{7}{|l|}{ School-Mean FSA Variables } \\
\hline 1999 FSA Score*(Y & $\begin{array}{l}0.037 \\
(0.024)\end{array}$ & $\begin{array}{l}-0.073^{* *} \\
(0.035)\end{array}$ & $\begin{array}{l}0.030 \\
(0.024)\end{array}$ & $\begin{array}{l}-0.184 * * * \\
(0.043)\end{array}$ & $\begin{array}{l}0.069 \\
(0.055)\end{array}$ & $\begin{array}{l}0.046 \\
(0.044)\end{array}$ \\
\hline 2000 FSA Score*(Yr=2001) & $\begin{array}{l}-0.013 \\
(0.020)\end{array}$ & $\begin{array}{l}-0.027 \\
(0.027)\end{array}$ & $\begin{array}{l}-0.005 \\
(0.021)\end{array}$ & $\begin{array}{l}-0.043 \\
(0.033)\end{array}$ & $\begin{array}{l}-0.043 \\
(0.044)\end{array}$ & $\begin{array}{l}-0.002 \\
(0.038)\end{array}$ \\
\hline \multicolumn{7}{|l|}{ Fraser Institute Variables } \\
\hline $\begin{array}{l}\text { 1999-2001 Mean FI } \\
\text { Score*(Yr=2002) }\end{array}$ & $\begin{array}{l}-0.001 \\
(0.006)\end{array}$ & $\begin{array}{l}-0.005 \\
(0.008)\end{array}$ & $\begin{array}{l}0.004 \\
(0.007)\end{array}$ & $\begin{array}{l}-0.017 * \\
(0.010)\end{array}$ & $\begin{array}{l}-0.020 \\
(0.015)\end{array}$ & $\begin{array}{l}0.003 \\
(0.012)\end{array}$ \\
\hline 2002 FI Scc & $\begin{array}{l}-0.006 \\
(0.005)\end{array}$ & $\begin{array}{l}-0.015^{* *} \\
(0.007)\end{array}$ & $\begin{array}{l}0.000 \\
(0.006)\end{array}$ & $\begin{array}{l}-0.012 \\
(0.010)\end{array}$ & $\begin{array}{l}-0.039 * * * \\
(0.012)\end{array}$ & $\begin{array}{l}-0.017^{*} \\
(0.010)\end{array}$ \\
\hline \multicolumn{7}{|l|}{ “Old News" Variables } \\
\hline 1999 & $\begin{array}{l}0.024 \\
(0.023)\end{array}$ & $\begin{array}{l}-0.026 \\
(0.035)\end{array}$ & $\begin{array}{l}0.019 \\
(0.025)\end{array}$ & $\begin{array}{l}-0.093^{* *} \\
(0.046)\end{array}$ & $\begin{array}{l}0.022 \\
(0.055)\end{array}$ & $\begin{array}{l}0.067 \\
(0.043)\end{array}$ \\
\hline 2000 FSA Score*(Yr>2001) & $\begin{array}{l}-0.018 \\
(0.019)\end{array}$ & $\begin{array}{l}-0.014 \\
(0.030)\end{array}$ & $\begin{array}{l}-0.025 \\
(0.021)\end{array}$ & $\begin{array}{l}-0.013 \\
(0.041)\end{array}$ & $\begin{array}{l}0.018 \\
(0.041)\end{array}$ & $\begin{array}{l}0.021 \\
(0.042)\end{array}$ \\
\hline $\begin{array}{l}\text { 1999-2001 Mean FI } \\
\text { Score* }(\mathrm{Yr}>2002)\end{array}$ & $\begin{array}{l}0.004 \\
(0.007)\end{array}$ & $\begin{array}{l}0.005 \\
(0.009)\end{array}$ & $\begin{array}{l}0.002 \\
(0.007)\end{array}$ & $\begin{array}{l}-0.001 \\
(0.012)\end{array}$ & $\begin{array}{l}0.022 \\
(0.019)\end{array}$ & $\begin{array}{l}0.006 \\
(0.013)\end{array}$ \\
\hline \multicolumn{7}{|l|}{$\begin{array}{l}\text { Current Mean FSA Variables } \\
\text { (Controls) }\end{array}$} \\
\hline Current FSA Score & $\begin{array}{l}-0.001 \\
(0.014)\end{array}$ & $\begin{array}{l}-0.015 \\
(0.026)\end{array}$ & $\begin{array}{l}-0.005 \\
(0.016)\end{array}$ & $\begin{array}{l}-0.057^{*} \\
(0.034)\end{array}$ & $\begin{array}{l}0.021 \\
(0.033)\end{array}$ & $\begin{array}{l}0.033 \\
(0.032)\end{array}$ \\
\hline Current FSA Score*(Yr>2001) & $\begin{array}{l}-0.013 \\
(0.019)\end{array}$ & $\begin{array}{l}0.021 \\
(0.031)\end{array}$ & $\begin{array}{l}-0.006 \\
(0.021)\end{array}$ & $\begin{array}{l}0.066 \\
(0.042)\end{array}$ & $\begin{array}{l}-0.039 \\
(0.046)\end{array}$ & $\begin{array}{l}-0.035 \\
(0.041)\end{array}$ \\
\hline Numb & 22145 & 14158 & 18078 & 7440 & 4067 & 6718 \\
\hline Number of schools & 353 & 354 & 336 & 346 & 321 & 286 \\
\hline
\end{tabular}

Source: Authors' calculations based on B.C. Ministry of Education enrollment and FSA exam databases.

Notes: Robust standard errors in parentheses, clustered at the school-by-year level. *** indicates statistically significant at the $1 \%$ level, ** indicates significant at the $5 \%$ level, * indicates significant at the $10 \%$ level. 
Table 6: Robustness of Effect of Information on Separation Probability. Grade 4 Students Enrolled in Lower Mainland Public Schools, 1999/2000-2003/2004

\begin{tabular}{|c|c|c|c|c|c|c|c|}
\hline & (1) & (2) & (3) & (4) & (5) & (6) & (7) \\
\hline & \multicolumn{3}{|c|}{ English only } & \multicolumn{4}{|c|}{$\begin{array}{c}\text { Fraser Institute Ranking instead of } \\
\text { Scores } \\
\end{array}$} \\
\hline & All & $\begin{array}{c}\text { Without } \\
\text { Aboriginals }\end{array}$ & $\begin{array}{l}\text { Without } \\
\text { Fr.Imm. }\end{array}$ & English & $\begin{array}{l}\text { Non- } \\
\text { English }\end{array}$ & Chinese & Punjabi \\
\hline \multicolumn{8}{|l|}{ School-Mean FSA Variables } \\
\hline $1999 \mathrm{~F}$ & $\begin{array}{l}-0.035^{* *} \\
(0.017)\end{array}$ & $\begin{array}{l}-0.032 * \\
(0.018)\end{array}$ & $\begin{array}{l}-0.036^{* *} \\
(0.017)\end{array}$ & $\begin{array}{l}0.035^{* *} \\
0.017)\end{array}$ & $\begin{array}{l}0.020 \\
(0.022)\end{array}$ & $\begin{array}{l}0.025 \\
(0.036)\end{array}$ & $\begin{array}{l}0.007 \\
(0.048)\end{array}$ \\
\hline 2000 FSA Score*( Yr =2001) & $\begin{array}{l}-0.027^{*} \\
(0.016)\end{array}$ & $\begin{array}{l}-0.024 \\
(0.016)\end{array}$ & $\begin{array}{l}-0.027 \\
(0.017)\end{array}$ & $(0.016)$ & $\begin{array}{l}-0.014 \\
(0.018)\end{array}$ & $\begin{array}{l}0.009 \\
(0.026)\end{array}$ & $\begin{array}{l}0.007 \\
(0.032)\end{array}$ \\
\hline \multicolumn{8}{|l|}{ Fraser Institute Variables } \\
\hline $\begin{array}{l}\text { 1999-2001 Mean FI Score*( Yr } \\
=2002) \\
2002 \text { FI Score*(Yr=2003) }\end{array}$ & $\begin{array}{l}-0.005 \\
(0.007) \\
-0.000 \\
(0.004)\end{array}$ & $\begin{array}{l}-0.004 \\
(0.007) \\
0.001 \\
(0.004)\end{array}$ & $\begin{array}{l}0.001 \\
(0.005) \\
-0.001 \\
(0.004)\end{array}$ & & & & \\
\hline $\begin{array}{l}\text { 1999-2001 Mean FI Ranking*( Yr } \\
=2002 \text { ) }\end{array}$ & & & & 0.001 & $\begin{array}{l}0.003 \\
(0.004)\end{array}$ & $\begin{array}{l}0.019 * * * \\
(0.007)\end{array}$ & $\begin{array}{l}0.006 \\
(0.009)\end{array}$ \\
\hline 2002 FI Ranking*( Yr =2003) & & & & $\begin{array}{l}-0.001 \\
(0.002)\end{array}$ & $\begin{array}{l}0.007 * * * \\
(0.003)\end{array}$ & $\begin{array}{l}* 0.014 * * * \\
(0.004)\end{array}$ & $\begin{array}{l}0.008 \\
(0.005)\end{array}$ \\
\hline \multicolumn{8}{|l|}{ “Old News" Variables } \\
\hline 1999 FSA Score*( Yr > 2000) & $\begin{array}{l}-0.008 \\
(0.017)\end{array}$ & $\begin{array}{l}-0.014 \\
(0.018)\end{array}$ & $\begin{array}{l}-0.010 \\
(0.017)\end{array}$ & $(0.017)$ & $\begin{array}{l}0.007 \\
(0.021)\end{array}$ & $\begin{array}{l}0.060 * \\
(0.033)\end{array}$ & $\begin{array}{l}-0.011 \\
(0.039)\end{array}$ \\
\hline 2000 FSA Score*( Yr >2001) & $\begin{array}{l}-0.012 \\
(0.016)\end{array}$ & $\begin{array}{l}-0.009 \\
(0.016)\end{array}$ & $\begin{array}{l}-0.013 \\
(0.016)\end{array}$ & $\begin{array}{l}0.015 \\
0.016)\end{array}$ & $\begin{array}{l}0.008 \\
(0.018)\end{array}$ & $\begin{array}{l}-0.005 \\
(0.024)\end{array}$ & $\begin{array}{l}0.052 \\
(0.038)\end{array}$ \\
\hline $\begin{array}{l}\text { 1999-2001 Mean FI } \\
\text { Score*(Year>2002) }\end{array}$ & $\begin{array}{l}-0.004 \\
(0.006)\end{array}$ & $\begin{array}{l}-0.005 \\
(0.006)\end{array}$ & $\begin{array}{l}0.001 \\
(0.005)\end{array}$ & & & & \\
\hline 1999-2001 Mean FI Rank*( Yr >2002 & & & & $\begin{array}{l}0.002 \\
(0.004)\end{array}$ & $\begin{array}{l}-0.006 \\
(0.004)\end{array}$ & $\begin{array}{l}0.000 \\
(0.006)\end{array}$ & $\begin{array}{l}-0.007 \\
(0.010)\end{array}$ \\
\hline \multicolumn{8}{|l|}{ Current FSA Variables (Controls) } \\
\hline Current Mean FSA Score & $\begin{array}{l}-0.008 \\
(0.012)\end{array}$ & $\begin{array}{l}-0.011 \\
(0.012)\end{array}$ & $\begin{array}{l}-0.007 \\
(0.012)\end{array}$ & $\begin{array}{l}-0.007 \\
(0.012)\end{array}$ & $\begin{array}{l}0.005 \\
(0.015)\end{array}$ & $\begin{array}{l}-0.020 \\
(0.021)\end{array}$ & $\begin{array}{l}0.005 \\
(0.033)\end{array}$ \\
\hline Current Mean FSA Score*(Yr>2001) & $\begin{array}{l}0.008 \\
(0.017)\end{array}$ & $\begin{array}{l}0.009 \\
(0.018)\end{array}$ & $\begin{array}{l}0.004 \\
(0.015)\end{array}$ & $\begin{array}{l}0.004 \\
(0.017)\end{array}$ & $\begin{array}{l}0.004 \\
(0.022)\end{array}$ & $\begin{array}{l}0.043 \\
(0.032)\end{array}$ & $\begin{array}{l}0.020 \\
(0.048)\end{array}$ \\
\hline Nun & 48149 & 44572 & 43931 & 48149 & 26219 & 10045 & 6041 \\
\hline Number of Schools & 362 & 362 & 358 & 362 & 361 & 318 & 261 \\
\hline
\end{tabular}

Source: Authors' calculations based on B.C. Ministry of Education enrollment and FSA exam databases.

Notes: Robust standard errors in parentheses, clustered at the school-by-year level. *** indicates statistically significant at the $1 \%$ level, ** indicates significant at the $5 \%$ level, * indicates significant at the $10 \%$ level. 
Table 7: Estimates based on Fraser Institute Ranking instead of Score, by Home Language and Quartile of Distribution of Mean Household Income, Grade 4 Students in Lower Mainland Public Schools, 1999/2000-2003/2004

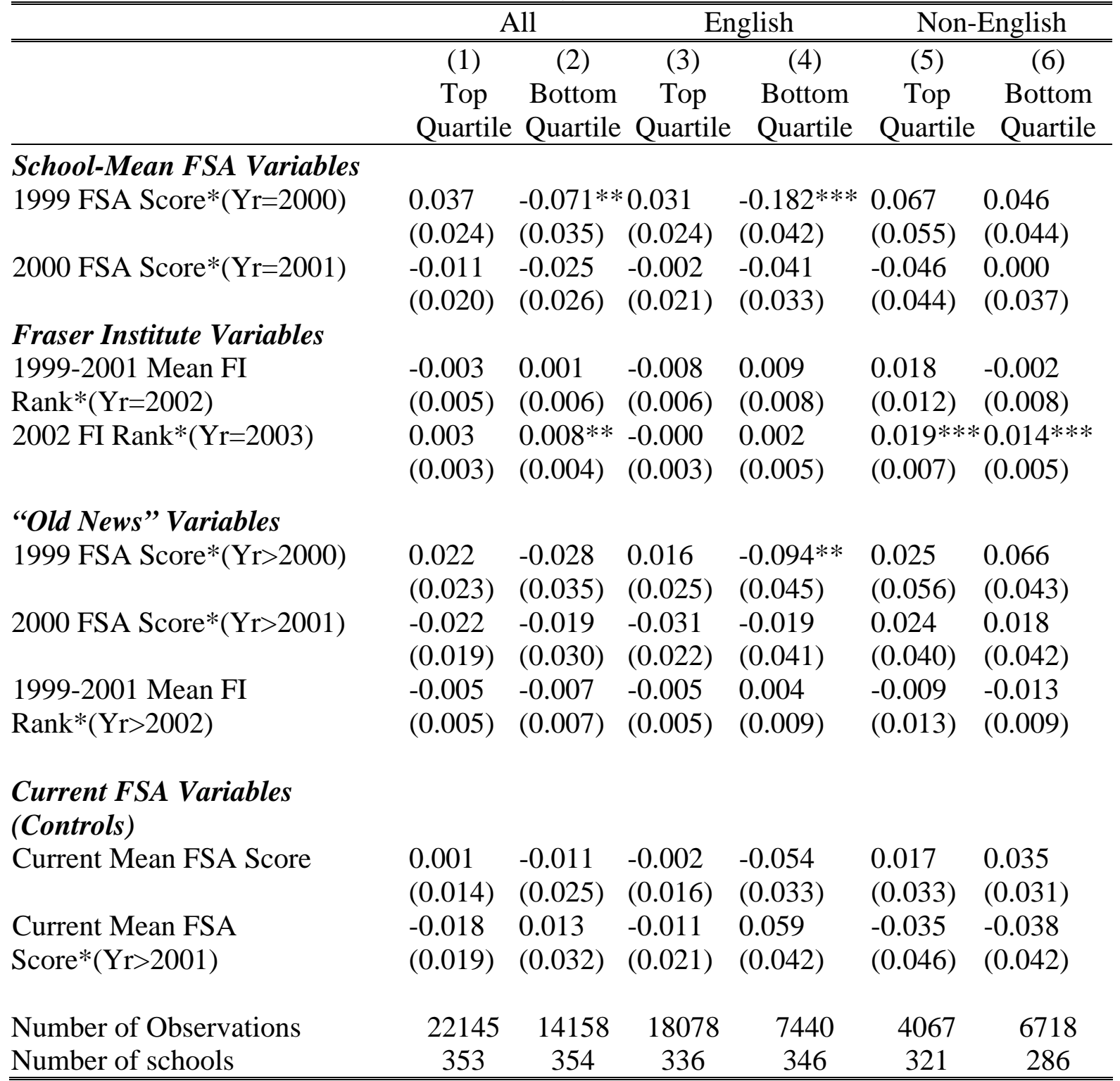

Source: Authors' calculations based on B.C. Ministry of Education enrollment and FSA exam databases.

Notes: Robust standard errors in parentheses, clustered at the school-by-year level. *** indicates statistically significant at the $1 \%$ level, ** indicates significant at the $5 \%$ level, * indicates significant at the $10 \%$ level. 